\title{
Female Sports Celebrities Targeting Female Teenagers: A Content Analysis Of Magazine Advertising
}

\author{
Melissa St. James, Ph.D., California State University Dominguez Hills, USA
}

\begin{abstract}
This study examined the usage of female sports celebrities as endorsers in magazines targeting female teenagers. Female sports figures act as role models for female teenagers and studies have shown they have a positive impact on self-image and self-identification. The Eriksonian Theory (Adams-Price and Greene, 1990), states that a "primary task of adolescence is the consolidation of ego identity." Teenagers often adopt the mannerisms, dress, and attitudes of celebrities as experimentation in their search for an identity. Theories of impression management and selfpresentation focus on aspirational identities; those that individuals want to attain or want to be associated with, in social interactions (Norman and Tedeschi, 1989). Teenagers relate to sports figures as teens are often active in sports as both participants and observers, and sports figures act as aspirational figures. Increasing the number of female athlete endorsement ads could be an innovative and effective marketing strategy.

A content analysis was conducted using the most recent $51 / 2$ years of SEVENTEEN, the top selling magazine targeting female teenagers. The proportion of celebrity athletes to celebrity non-athletes and the proportion of female to male celebrity athlete endorsers were recorded. Product category endorsed and nature of portrayal or depiction of the celebrity athlete, with respect to expert condition and appearance, were also examined. This study has revealed encouraging strides in the depiction of female athlete endorsers in teen magazines. The results show female athletes are being used to target female teens and are being portrayed as expert, engaged in athletic activity, and non-suggestive.
\end{abstract}

Keywords: advertising, celebrity endorsement, teenager, content analysis exploratory

\section{INTRODUCTION}

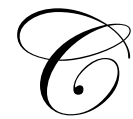

elebrity endorsement advertising has been around for over 150 years, and celebrity athletes have often topped the list of most popular and most highly paid endorsers. In the 1920s, even Babe Ruth was a pitchman for candy bars (Kaikati, 1987). The total number of athlete endorsements has varied across decades. One study showed one celebrity athlete endorsement advertisement in 1920, 21 in 1930, then a drop to 11 and 10 in the 30s and 40s, respectively. Since then, the numbers have risen, experiencing another drop in the 1980s, but rebounding in the 1990s (Kahle and Riley, 2004). After the 1996 Olympic Games, women began receiving endorsement contracts notable in both number and dollar amount.

While it is true that fewer female than male athletes have endorsement contracts and the amount per contract for female athletes is lower (Fink and Parker, 2008; Spencer and McClung, 2001), the trend over the past three decades has been an increase in the number of advertisements using female athletes as endorsers (Kahle and Riley, 2004). A 1997 Sports Marketing Newsletter showed a top 10 athlete endorser earnings list exclusively male. By 2004, the "sports in order of comfort level in making marketing officers confident in using a celeb(rity) are: auto racing, amateur athletics, baseball, football, basketball and hockey," none of which are predominately engaged in by females (Ebenkamp, 2004). However, Danica Patrick (auto racing) and Diana Taurasi (basketball) both have prominent endorsement deals. 
However, in 2000, tennis star Venus Williams signed a $\$ 40$ million contract with Reebok, one of the largest single endorsement contracts any athlete has ever received (Bonham, 2000). And, females signing endorsement contracts began an upswing. Forbes.com ranked athletes by endorsement income less average endorsement income of their top 10 peers and Maria Sharapova ranked $7^{\text {th }}$ for 2006 with a value of $\$ 10$ million. This figure was still $\$ 54$ million behind number one ranked Tiger Woods. SI.com, in their 2008 Fortunate 50 ranking of the highest earning athletes in the U.S., presented a top 10 all-boys club of athletes earning a total of $\$ 273,250,000$ from endorsements alone (http://sportsillustrated.cnn.com/more/specials/fortunate50/2008/). It is clear that females have a long way to go in order to match male athletes in endorsements, but an increase is occurring.

Teenagers, as of the late 1990s, represented the fastest growing population segment and the largest youth market since the Baby Boomers, according to the Kaiser Family Foundation (2004). This market (12-19 year olds) spends over 200 billion dollars annually and are avid readers of magazines, with one survey putting the number of 11-18 year olds reading magazines on a regular basis at $66 \%$. Moreover, this survey by the Taylor Research \& Consulting Group found that 12-15 year-old girls look to magazines as much as they do their friends when seeking trends (2003). Girls also tend to use magazines to assist in formulating their identity (Duke and Kershel, 1998). It has also been shown that teenage girls are more apt to spread positive word of mouth regarding products endorsed by a favorite female athlete than are teenage boys and that female athletes serving as role models can influence brand choice (Bush, Martin and Bush, 2004).

Female endorsers have also been shown to be more credible than male endorsers (Goldman, 1995; St. James and Swartz, 2004), and teenagers have been shown to be heavily influenced by celebrity endorsers (Bush, Martin and Bush, 2004; Stanton, Currie, Oei, and Silva, 1996; Atkins and Block, 1983). It is therefore imperative to examine the practice of using female athletes as endorsers in magazines targeting teenage females (Goldman, 1995; Adams-Price and Greene, 1990).

Celebrity endorsements can be expensive and risky, whether the celebrity is an athlete or an entertainer. The top 10 celebrity athlete endorsers earned a combined $\$ 273,250,000$ in 2008 (SI.com, 2009). The long history of celebrity endorsement advertising contains many failed or aborted endeavors, including O.J. Simpson (Hertz Rental Car), Madonna (Pepsi), Celine Dion (Chrysler), and recently several athletes, including Kobe Bryant, Michael Vick and even golden boy Michael Phelps, have encountered lost endorsements related to their negative (and sometimes criminal) behavior. Advertisers must choose celebrity endorsers carefully in order to maximize their return and build brand equity and goodwill.

This research study combines a look at celebrity endorsements, athlete endorsements in particular, the rationales for their effectiveness, including their effect on teenagers, and a summary of a content analysis performed for this research endeavor. Conclusions and recommendations for future research are also included.

In an effort to build on previous research by Grau, Roselli and Taylor (2007), this current study addresses the following research questions:

In Seventeen, the top teen magazine targeting females, for the past $51 / 2$ years:

1. Which categories of celebrities are represented in endorsement ads and in what proportions?

2. What product category do celebrity female athletes most often endorse?

3. Are female athletes portrayed as expert or non-expert, based on depiction as athlete vs. model in the ad?

4. Are female athlete endorsers more often individual sport or team sport participants?

5. Are female athletes portrayed as sexy more often than not?

This study is exploratory in nature and seeks to examine the current state of female celebrity endorsement advertising in magazines aimed at teenage girls. Grau et. al. (2007) compared female athlete endorsement advertisements to male athlete endorsements across a broad range of magazines from 2002 through 2005. This current study examines Seventeen, the leading magazine targeting teenage girls, over a $5 \frac{1}{2}$ year period, from January 2004 through August 2009. The comparison here is among celebrity types, product categories and depictions of the athletes rather than across magazines and genders. 


\section{LITERATURE REVIEW}

\section{Female Athletes}

If society wants young girls to grow and fulfill their potential, good role models are essential. And, as role models, athletes embody many positive traits such as determination, fitness and team spirit. Girls, in increasing numbers, have been engaging in athletic endeavors in the years since the passage of Title IX in 1972.

- In 1971, 1 out of 27 girls participated in high school sports; In 1998, 1 out of 2.5 (For boys, the ratio froze at 1 out of 2.)

- In $1980,10 \%$ of marathon finishers were women; by 2001 , about $30 \%$

- $\quad$ In the 1990s, the number of girls on school sports teams increased $31 \%$ (boys, $9 \%$ ).

- $\quad$ From 1990 to 1996 women's college-soccer participation increased 120\% (Sullivan, 2001).

As noted in Grau et. al. (2007), media coverage of female athletes has lagged greatly behind that of males. The 1996 Olympic Games, when NBC aired moments of female athletic feats, should have been the beginning of a new era in equal coverage. The low numbers reported by Grau et. al. reflect this not coming to fruition as quickly as had been hoped:

- $\quad$ Sports Center and Sports Tonight airing $8.7 \%$ female coverage even though females were at $40 \%$ of total participation (Grau, et. al., 2007).

- 1997 to 2003, ESPN the Magazine, showed only two female athletes on the cover-Marion Jones and Serena Williams.

- $\quad 1999$ - Sports Illustrated featured two individual female athletes on the cover, Serena Williams and Brandi Chastain, and one female group of sportswomen of the year.

- 2000 - SI showed six covers featuring females, excluding the Annual Swimsuit issue (Marion Jones, Anna Kournikova, Shea Ralph, a female portraying a fan, Megan Quann, anonymous fan with a bag on her head.).

- $\quad 2001-$ SI featured the Dallas Cowboys cheerleaders on one cover.

Then, in the ensuing years, the following number of SI covers featured women (excluding the Annual Swimsuit issues):

- 2002 - three covers; a special report issue on colleges featured multiple athletes of both sexes, Sarah Hughes, and Sue Bird.

- 2003 - four covers; Mia Hamm, Diana Taurasi (with Emeka Okafor), a woman diver with Pipin Ferreras, and Serena Williams.

- $\quad 2004$ - two covers; US Women's Olympic Softball team and Maria Sharapova

- 2005 - two covers; Jennie Finch and Danica Patrick. (Grau, et. at., 2007).

Since 2005 SI has featured women on its cover the following number of times in each year (excluding the Annual Swimsuit issues):

- $\quad 2006-1$ group shot with both male and female Olympic boarders, and a special issue with thumbnail photos of multiple athletes on the cover including three females (out of approx. 23).

- 2007 - one cover featured Candace Parker and one featured Ohio State cheerleaders and fans (mixed sexes).

- $2008-$ one cover - Danica Patrick (SI.com).

This apparent lack of coverage of women's athletics does not seem to be decreasing as one would expect. If this is "a result of the attitudes, opinions, and practices of the sports editors" (Grau, et. al., 2007), one can only hope that increased participation by females in sports will turn the tide as the new generations come of age. 


\section{Celebrity Endorsers and their Impact on Teenagers}

Advertisers have been featuring celebrity endorsers in ads since the 1800s. In 1864 The Poland Company used a testimonial from Rev. J.K. Chase in an advertisement (Kaikati, 1987) and one of the earliest true celebrity endorsement ads, featuring Sarah Bernhardt for Pear's Soap, appeared in 1897. Celebrity endorsements' impact on advertising effectiveness has both support and dissent in research, with a wealth of research in the area. Erdogan, in 1999, conducted a literature review of over 45 celebrity endorsement articles from various academic marketing and communication journals and a recent search of scholarly journal articles revealed over 50 articles published since 2000 (Erdogan, 1999).

In this body of research there exists evidence that celebrity endorsers are likeable and attractive, can serve as attention-getting devices and can aid in recall (Kamins, 1990). Others have found that, although attention and recall are important, forming favorable attitudes and purchase intentions is the road to actual purchase behavior (Kamins, Brand, Hoeke and Moe, 1989). Additional findings in the body of celebrity endorsement literature include: formation of a distinct personality for the brand (McCracken, 1989), positive attitude toward the brand (Kamins et al., 1989), enhanced brand name recognition (Petty, Cacioppo and Schumann, 1983), and enhanced message recall (Friedman and Friedman, 1979).

This article examines celebrity athlete endorsers in the top selling magazine aimed at teenage girls. A brief understanding of how teenagers form their self-view and how celebrity endorsers can have an impact on selfpresentation style is important. According to Kover, Goldberg and James (1995),

"the key pathway in looking at advertising [effectiveness] is to reinforce the individual's ideal self and, in doing so, increase favorable attitude toward both advertising and the brand or product advertised."

The idea addressed in this paper is that the source (the celebrity endorser) can have an effect on the selfpresentation style of the teen-aged consumer, and as such can be used as a tool in the course of the persuasion process. Consumers can be affected by qualities the celebrity embodies such as attractiveness and perceived image, or credibility, defined by Ohanion as a combination of expertise, trustworthiness and attractiveness (Ohanion, 1991). Grant McCracken's 1989 study proposing a meaning transfer model as an approach to studying celebrity endorsement effectiveness provides a strong basis for this overall assumption.

A celebrity endorser has been previously defined as an individual who is known to the public (e.g., an actor, a sports figure, an entertainer) for his or her achievements in areas other than that of the product class they are endorsing (Friedman and Friedman, 1979). For this research endeavor, that definition is expanded to include those celebrities who endorse products connected to their area of expertise or fame (i.e., Michael Jordan endorsing athletic apparel or shoes).

McCracken's theory, in essence, states that a celebrity embodies cultural meanings that are passed from the celebrity to the product, and in turn to the consumer. This meaning transfer ensures the celebrity endorser's effectiveness in the persuasion process. Teenaged consumers, perhaps due simply to the nature of being a teenager, respond to celebrity endorsements. Adams-Price and Greene (1990) refer to the Eriksonian theory that a "primary task of adolescence is the consolidation of ego identity." Teenagers tend to adopt mannerisms, dress, and even attitudes of heroes and celebrities as an experimentation. They try out roles and identities as a means of social interaction. Theories of impression management and self-presentation focus on identities that individuals want to attain or be associated with in their social interactions (Norman and Tedeschi, 1989). Teenagers are easily persuaded to incorporate opinions and personality characteristics of others into their self-concepts and to rely on social influences when forming their identities.

There are an estimated 28 million 12-to-19-year-old consumers in the U.S. and the typical adolescent spent $\$ 2,331$ in 1988 (Sellers, 1989). Advertisers are faced with not only attracting consumers' attention to their product but also transforming that attention into a favorable attitude toward the product. Ultimately their goal is transforming that attitude into a purchase intention and consumer action. Accountability for advertising dollars is mandatory as competition increases and consumers have more choices. Teenagers as a target market, with a total estimated impact on the U.S. economy of $\$ 248.7$ billion, cannot afford to be overlooked by advertisers (Sellers, 1989). 


\section{Effectiveness of Celebrity Endorsers}

Michael Kamins (1989) illustrated that the use of celebrity endorsers is effective because of the identification process. This process is one of three social influence processes identified by Herbert Kelman (1961) through which an individual may adopt an attitude advocated by a communicator, in this case, the celebrity endorser. Of the three processes: compliance, identification and internalization; identification and, to a degree, internalization have been shown to be important to the study of celebrity endorsers in advertising.

Compliance, when a person is influenced by someone advocating a position or product in the hope of getting a favorable reaction from the communicator is not applicable to celebrity endorser advertising. In effect, the consumer has little chance of being acknowledged by the celebrity endorser for having purchased the product (Kamins, 1989).

Identification is related to the attractiveness and likeability of the celebrity endorser. Identification relies on the receiver adopting the attitude of the endorser because the receiver wants to emulate or be like the endorser (Kamins, 1989). Teenagers are highly motivated by the idea of being thought of well by others, and this is important in building a selfconcept and looking to self-enhance. Emulating a celebrity one feels represents desirable qualities is a method of impression management. Adopting gestures, dress, appearance or speech patterns of a celebrity are all ways of manipulating one's self image in the presence of others for a purpose (self-presentation): to been seen in a favorable light by others. Teenagers' experimentation with identities and roles through identification with celebrities is an important aspect of their self-concept formulation (Adams-Price and Greene, 1990).

Internalization, is not strongly linked to celebrity endorsement advertising because celebrities are sometimes seen as "doing it only for the money" and the believability of the ad becomes questionable. In combination with identification, however, internalization can be a means of encouraging self-enhancement and attitude change. Internalization can be a valid self-presentation management tool only if the attitude of the communicator is consistent with the consumer's own values.

Kamins' follow up study “An Investigation into the Match-Up Hypothesis in Celebrity Advertising: When Beauty May be Only Skin Deep" (1990) addresses the issue of believability by testing the hypothesis that the attractiveness of a celebrity endorser may enhance attitudes and purchase intentions but only when the images of the product and the celebrity "match-up." Since self-presentation and impression management rely on the idea of individuals striving to promote an image of themselves in other's eyes, presenting oneself as associated with the celebrity by purchasing the endorsed product is a way of identifying with the celebrity. One is essentially using the product as a bridge for incorporating attributes identified with the celebrity into one's own self-presentation.

Lockwood and Kunda (1997) found that if an individual feels the success of the role model was reasonably attainable, then the star provoked self-enhancement. However, the self-view was only affected if the star's domain was relevant to the individual in some way. Teenagers relate well to sports figures since teenagers are often particularly active in sports as both participant and observer. Teenagers feel that anything is possible for them, the NBA, the PGA or the NFL, and sports figures are looked to as role models.

\section{Credibility of the Celebrity Endorser}

When discussing credibility it has been shown by several researchers that a highly credible source is more effective, produces more positive attitudes toward the product or position endorsed and results in more behavioral changes than a less credible source (Buhr, Simpson and Pryor, 1987). Self-enhancement theory indicates that the individual wants to be thought of well by others and would therefore be influenced more by a credible source to create a positive association.

Previous literature identified three dimensions of source credibility: expertise, trustworthiness and attractiveness (Kahle and Homer, 1985; Maddux and Rogers, 1980; Ohanian, 1991). Expertise, defined by Ohanian as "the knowledge that the communicator seems to possess to support the claims made in the advertisements"; trustworthiness is rooted in the consumers' confidence that the communicator is honest and objective in providing information in the advertisement; and attractiveness of the source as a component of source credibility has direct ties to the use of celebrities as endorsers 
since most celebrities tend to be attractive to the general public (Ohanian, 1991). These are all positive traits in a celebrity that one may want to emulate or incorporate into one's self-presentation. It must be noted that adolescents are also susceptible, however, to influence from celebrities in ways that can produce adverse effects. Celebrity endorsements of alcohol products are particularly effective with teenagers because the celebrity figure is seen by the teenagers as trustworthy and more competent than ordinary spokespersons (Atkin and Block, 1983). Also, the influence of a celebrity on teenagers' smoking habits increased in late adolescence, according to Stanton et. al. (1996) because the teenagers felt that the celebrity wouldn't endorse a product harmful to them.

\section{Meaning Transfer Model}

McCracken's alternative meaning transfer theory is that a celebrity is endowed with cultural meanings which are passed from the celebrity to the product. These meanings are then passed to the consumer, ensuring the celebrity endorser's effectiveness in the persuasion process (McCracken, 1989).

The cultural meanings embodied in celebrities have power that unknown actors or spokespersons cannot match (McCracken, 1989). Celebrities' visibility and longevity assist this - we have come to associate meanings with them because we have watched them in movies, or on the athletic field, or on the stage, display these qualities repeatedly. Impression management and self presentation through incorporating or taking on the cultural meanings associated with the celebrity is a means of identification.

The idea that we all find meanings in our possessions and use these meanings to create selves is part of the process (McCracken, 1989). The public nature of the celebrity-created self, now endowed with cultural meanings, makes the celebrity inspirational to the consumer (McCracken, 1989). Adams-Price and Greene (1990) found that adolescent boys in particular formed identificatory attachments to celebrity figures. These secondary attachments, in which adolescents expressed a desire to be the attachment object, created relationships that were important in the development of their social identity. These attachments serve as a method of incorporating characteristics attributed to the celebrity into the teenagers' self concept.

Those in need of self enhancement are often those in need of the meanings created by celebrities. These meanings become available to consumers through the meaning transfer process as a method of self-enhancement. Anyone undergoing a life change or major change in status can be dependent on their possessions for meaning (Solomon, 1983). Since adolescence can arguably be defined as a major life change, teenagers, struggling with role confusion and trying on various identities through associations with others, are particularly susceptible to social influences provided by celebrity endorsers.

\section{HYPOTHESES}

Given the lack of focus on female athletics mentioned earlier, one would assume that there would be fewer celebrity athlete endorsers depicted than other celebrity endorsers and that there would be more male than female athletes endorsing products. However, examining Seventeen magazine, which is arguably aimed exclusively at teenage girls, skews this second assumption. Therefore, it is expected that:

H1a: There will be fewer celebrity athletes endorsing products in Seventeen magazine compared to other celebrity categories.

H1b: There will be more female athletes endorsing products in Seventeen magazine compared to male athletes.

Teenagers, attempting to create selves and enhance image, are drawn to celebrities they aspire to be like. If celebrities influence teenagers, as previous research has shown, one would assume that credibility and desirable cultural meanings would be considered important factors. Examining whether the celebrity is portrayed endorsing a matched or appropriate product would be useful. If, as indicated in Grau et. al. (2007), female athlete endorsers are seen as female first and athlete second, it is expected that:

H2: There will be more female athletes endorsing cosmetics/personal and clothing/shoe products compared to other product categories. 
The depiction or portrayal of the athlete as expert, shown with athletic gear and/or engaging in athletic activity, in the advertisement is key to the credibility issue. If the celebrity is portrayed with her athletic gear, even actively participating in her sport, she may be viewed as more credible than if she is portrayed as just another pretty face. It is also assumed that if female athletes are viewed as more feminine if they engage in individual sports as compared to team sports (Grau et. al. (2007), there should be more female athletes depicted from individual sports than team sports. It is therefore assumed that:

H3: There will be more female athlete endorsers portrayed as expert compared to non-expert.

H4: There will be more female athlete endorsers from individual sports compared to team sports.

It has been previously noted that attractiveness plays a large role in the effectiveness of celebrity endorsement advertising effectiveness. If female celebrities are indeed portrayed as sexy and used "for the sexuality and attractiveness" rather than for their athletic abilities and expertise (Grau et. al., 2007), then one would expect that female celebrity athletes would be portrayed as suggestive even in teen magazines. However, if the females are portrayed as expert athletes, this may skew this as well. It is expected then that:

H5: There will be more female athlete endorsers depicted as demure compared to suggestive.

\section{METHODOLOGY}

\section{Content Analysis}

Teenagers, engaged in their struggle to create selves, to fit in with peer groups, and to be liked, are undeniably more vulnerable to the social influences of celebrity endorsers than are older consumers. Literature examined for this discussion was somewhat limited, although it predominately supports the theory that teenagers' self-concepts and selfpresentation styles are influenced by celebrity endorsers. The following content analysis was performed as an examination of the usage of female athlete celebrities in advertising aimed at teenage girls.

The content analysis was conducted using every issue of Seventeen magazine, the top selling magazine targeting female teenagers according to Magazine Publishers of America (http://magazine.org) from January 2004 to August 2009. Each issue was examined and the celebrity endorsement advertisements were coded as to:

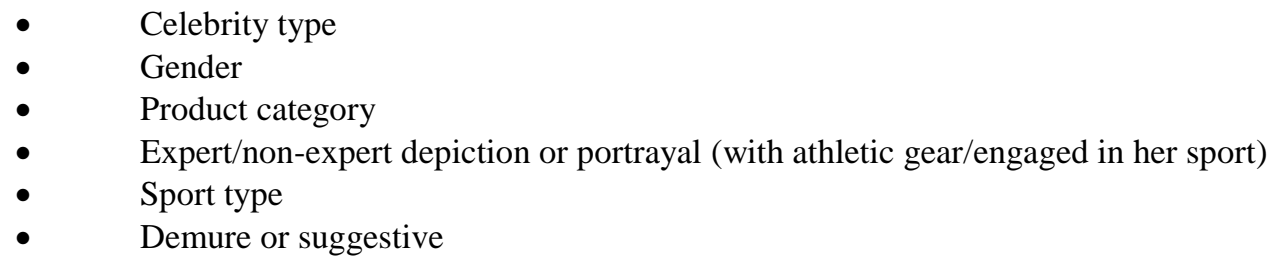

The author and two independent coders, trained by the author, coded the advertisements. Differences were reconciled by review and discussion until a consensus was reached. Coders were provided codebooks containing operational definitions and category lists for coding, following Grau et. al.'s example (2007), which in turn was based on Kolbe and Burnett's guidelines (1991).

First, all ads containing celebrity endorsers were counted and coded as to type of celebrity (athlete, singer, actress, etc...) and gender of celebrity. Following the methodology used by previous researchers, only ads including professional athletes endorsing products were counted as celebrity athlete endorsements, with double page ads being counted as a single advertisement. Duplicate ads were included and counted, again in keeping with previous studies (Grau, et. Al., 2007; Wilkes and Valencia, 1989; Stevenson and McIntyre, 1995).

The product category and the sport type lists were adapted from Grau et. al., with an expansion of the sport type list to include gymnastics, cheerleading and auto racing. The portrayal of the endorser as sexy versus non-sexy was addressed with a modified coding based on Reichert et. al. (1991), using only the demure and suggestive categories (no 
nude portrayals were found in any issue and the few "partially clad" portrayals - swim suits, lingerie and revealing workout attire - were so mild as to be coded "suggestive"). The question of portrayal as expert versus non-expert was coded based on whether the endorser was shown in their athletic environment with athletic gear while endorsing products. For example, a professional soccer player depicted on the soccer field would be coded "expert" while the same soccer star depicted without athletic gear or connection in the ad would not.

\section{RESULTS}

Table 1 below shows the largest proportion of female celebrity endorsers is clustered within the actress/actor and singer/musician categories (accounting for $82.5 \%$ of the total celebrity endorsement advertisements). The percentage of athlete endorsement ads is somewhat underwhelming at $12.1 \%$., although it is the third highest category. Further examination of the data collected, however, revealed that noncelebrity athletes (***models dressed like and/or acting like athletes) were portrayed in the magazine 61 times, with 57 ads containing females alone and the remaining 4 ads containing both male and female amateurs athletes. While this current research study was aimed at examining only celebrity athlete endorsers, it is encouraging to see that females are being shown in the magazine advertisements engaging in athletic pursuits. Therefore, H1a is supported (chisquare $=199.334, \mathrm{p}=.000)$.

Based on Table 1, H1b is also supported (chi-square=43.429, p=.000). Significantly more female celebrity athletes are depicted endorsing products in Seventeen magazine compared to male celebrity athletes. In addition, the number of female celebrities of all types greatly outnumbered the male celebrities and, as mentioned above, the number of non-celebrity female athletes appearing in advertisements was 14 times as large as the number of male non-celebrity athletes.

\begin{tabular}{|c|c|c|c|c|c|c|}
\hline Type of Celebrity & Total ads & $\%$ & Female & $\%$ & Male & $\%$ \\
\hline Athlete & 42 & 12.1 & $35^{*}$ & 83.3 & $8^{*}$ & 19.0 \\
\hline Actress/Actor & 139 & 40.1 & $133 * *$ & 95.7 & $13 * *$ & 9.4 \\
\hline Singer/Musician & 147 & 42.4 & 141 & 95.9 & 6 & 4.1 \\
\hline TV Personality & 12 & 3.5 & 11 & 91.7 & 1 & 8.3 \\
\hline Beauty Contestant/Winner & 7 & 2.0 & 7 & 100.0 & 0 & 0.0 \\
\hline Totals & 347 & 100.0 & 327 & 94.2 & 28 & 8.1 \\
\hline
\end{tabular}

*2 advertisements contained both males and females; these ads are not counted twice in the total ads column.

**7 advertisements contained both males and females; these ads are not counted twice in the total ads column.

The breakdown across product categories of the female athlete endorsements is shown below in Table 2 . Regarding H2 (There will be more female athletes endorsing cosmetics/personal and clothing/shoe products compared to other product categories), we can see that this hypothesis is not fully supported (chi-square=.111, $\mathrm{p}=.739$ ). The number of clothing/shoe/apparel and cosmetic ads featuring female athletes was not significantly higher than the number of other product category ads.

Of the 42 celebrity athlete endorsements found, 20 fell into the clothing/apparel and cosmetics/personal care categories combined while 22 were for food and beverages. Females were featured in 19 of the 20 ads for clothing/shoes and cosmetics (combined) and in 17 of the 22 ads for food and beverages. While the hypothesis does not address the number of females vs. males endorsing the various product categories, it is interesting to note that $100 \%$ of the clothing and apparel ads featured females and $91.7 \%$ of the cosmetics and personal care ads featured females. The other product category represented by celebrity athlete endorsers was Food and Beverages, and females were featured in $77.3 \%$ of those ads. This is notably different from the earlier study which found no female athletes endorsing cosmetics and personal care products and 34 male vs. 3 female athletes endorsing clothing/shoes/apparel (Grau et. al., 2007).

The fact that $\mathrm{H} 2$ was not clearly supported is interpreted as positive. It appears that, in Seventeen magazine, female celebrity athletes are not being stereotyped by endorsing only product categories traditionally perceived as 
feminine. Female athletes were portrayed in an almost equal number of clothing/shoe/apparel ads as other product categories combined.

Table 2: Type of Product Endorsed by Athletes

\begin{tabular}{|c|c|c|c|c|c|}
\hline Type of Product & Total ads & Female & $\%$ & Male & $\%$ \\
\hline Clothing/Shoes/Apparel & 8 & 8 & 100 & 0 & 0 \\
\hline Exercise and Diet & 0 & & & & \\
\hline Sporting Goods & 0 & & & & \\
\hline Cosmetics and Personal Care & 12 & $11 *$ & 91.7 & $3 *$ & 25 \\
\hline Food and Beverages & 22 & 17 & 77.3 & 5 & 22.7 \\
\hline Automobile & 0 & & & & \\
\hline Over the Counter Drugs & 0 & & & & \\
\hline Electronic Appliances & 0 & & & & \\
\hline Entertainment & 0 & & & & \\
\hline Publications & 0 & & & & \\
\hline Retailers & 0 & & & & \\
\hline Banking & 0 & & & & \\
\hline Transportation & 0 & & & & \\
\hline Non Profit Organizations & 0 & & & & \\
\hline Miscellaneous Products & 0 & & & & \\
\hline Miscellaneous Services & 0 & & & & \\
\hline $\begin{array}{c}\text { Totals } \\
\end{array}$ & 42 & 36 & 85.7 & 8 & 19.0 \\
\hline
\end{tabular}

*2 advertisements contained both male and female athletes; these ads are not counted twice in the total ads column.

$\mathrm{H} 3$, relating to the expert condition vs. the non-expert condition, was clearly supported, as shown in Table 3 below (chi-square=11.111, $\mathrm{p}=.001$ ). The ads were coded expert or non-expert based on whether the athlete was pictured with her athletic gear and or engaging in her athletic activity, implying expert condition rather than simply an attractive appearance. The data indicates that the female celebrity athletes were depicted actively engaged in their respective athletic endeavors in more than $3 / 4$ of the advertisements.

Table 3: Portrayal-Expert vs. non-expert

\begin{tabular}{|c||c||c|c|c|}
\hline Total ads & $\begin{array}{c}\text { With gear - } \\
\text { Actively athletic }\end{array}$ & $\%$ & $\begin{array}{c}\text { Without gear - } \\
\text { Not actively athletic }\end{array}$ & $\%$ \\
\hline 36 & $28^{*}$ & $\mathbf{7 7 . 8}$ & $\mathbf{8}$ & $\mathbf{2 2 . 2}$ \\
\hline
\end{tabular}

*2 advertisements contained both male and female athletes; these ads are included in the total ads column.

Table 4 shows the number of female celebrity endorsement ads by type of sport. H4 examined whether ads depicting females from individual sports were more common than those that portrayed female athletes from team sports. This hypothesis is clearly supported as 32 of the 36 ads $(88.9 \%)$ depicted athletes from individual sports and 4 of the ads depicted athletes from team sports $(11.1 \%)$ (chi-square $=21.778, \mathrm{p}=.000)$.

Finally, H5 examined the depiction of the female athlete as "demure" or "suggestive" based on the level of sex appeal in the advertisement. This was coded based on dress and demeanor of the athletes as depicted in the ads. Of the 34 ads depicting females alone, only 2 (5.9\%) were coded as "suggestive". These ads, two instances of the same Danica Patrick "Got Milk?" ad, were coded as suggestive based on the form-fitting leather jumpsuit and sultry demeanor of the athlete. It is interesting to note that Danica was coded as expert based on the fact that she was attired in racing gear and carrying a racing helmet. The two ads depicting both male and female athletes, (again two instances of the same ad, for Team Paul Mitchell) portrayed one female in a bikini top with her jacket open. This ad was not deemed suggestive by the coders based on the casual and non-suggestive demeanor of the athlete. It appears that H5 was supported. The proportion of demure ads greatly exceeded the proportion of suggestive ads and this 
difference was significant (chi-square=28.444, $\mathrm{p}=.000$ ). The support for this hypothesis actually bodes well for female athlete endorsers as it indicates they are portrayed for their athletic abilities rather than simply as ornamentation.

Table 4: Type of Sport

\begin{tabular}{|c|c|}
\hline Type of Sport & Total \# of ads depicting females \\
\hline Team Sports-TOTAL & $4(11.1 \%)$ \\
\hline \multicolumn{2}{|l|}{ Cheerleading } \\
\hline \multicolumn{2}{|l|}{ Volleyball } \\
\hline \multicolumn{2}{|l|}{ Football } \\
\hline Basketball & 4 \\
\hline \multicolumn{2}{|l|}{ Hockey } \\
\hline \multicolumn{2}{|l|}{ Baseball/softball } \\
\hline \multicolumn{2}{|l|}{ Soccer } \\
\hline Individual Sports-TOTAL & $32(88.9 \%)$ \\
\hline \multicolumn{2}{|l|}{ Golf } \\
\hline Tennis & 5 \\
\hline Boxing & 1 \\
\hline Ice Skating & 8 \\
\hline \multicolumn{2}{|l|}{ Cycling } \\
\hline Surfing/Skateboarding & $6^{*}$ \\
\hline \multicolumn{2}{|l|}{ Track and Field } \\
\hline Extreme Sports & 6 \\
\hline \multicolumn{2}{|l|}{ Wrestling } \\
\hline Gymnastics & 1 \\
\hline Auto Racing & 2 \\
\hline Other & 3 \\
\hline Totals & 36 \\
\hline
\end{tabular}

*2 advertisements contained both male and female athletes; these ads are included in the total ads column.

\section{CONCLUSIONS AND RECOMMENDATIONS}

While the number of contracts, and the dollar amounts of those contracts, has increased over the past 30 years, there are still a small number of female athletes touting products, particularly to teenage girls, compared to other celebrity categories. While Grau et. al. found “...only five ads that featured athlete endorsers; and none were female...", that study examined a limited number of issues of the magazine ("... six (monthly) to eight (weekly) issues of each magazine ...from the time period September 2002 to February 2005...”), (2007). This current study examined every issue of Seventeen magazine covering the most recent 5 1/2 year period in its entirety and found far more female than male athlete endorsement ads.

The total number of athlete endorsement ads is still small compared to the number of non-athlete celebrity endorsement ads. This study yielded 347 total celebrity endorsement advertisements; 42 of those (12.1\%) were athlete celebrity endorsements compared to $305(87.9 \%)$ non-athlete celebrity endorsement ads. It is encouraging to note that $83.3 \%$ of those non-athletes portrayed were female.

The literature examined above showed that associations with celebrities through the endorsement process is a means by which consumers, in particular teenage consumers, can manage their image through adoption of cultural meanings associated with celebrities. In striving to maintain positive self-views, self-presentation plays a large role. In "striving to promote the perception that others think well of you," celebrity endorsers play a role in supplying the cultural meanings upon which consumers can draw. 
This study has revealed encouraging strides in the depiction of female athlete endorsers. The results show female athletes are being used to target female teens and are being portrayed as expert, engaged in athletic activity, and non-suggestive. The product categories endorsed, while limited, cover more than just "girly" products like cosmetics and clothes.

Media has a great influence on teens in their quest to establish an identity and independence (Bush, Martin, and Bush 2004). Studies have shown female sports figures can act as role models, they can have a positive impact on young people's self-image and self-identification, and women endorsers are seen as more credible than men. Given this, the impact of positive female athlete role models endorsing products aimed at teenage girls can only enhance teenage girls' self-view (Goldman, 1995). Female athletes in product endorsements contained within magazines targeting teenage girls can be an innovative, effective method of encouraging positive self-enhancement among young girls.

\section{AUTHOR INFORMATION}

Melissa St. James is an assistant professor of marketing in the Management and Marketing Department at California State University Dominguez Hills. She earned her PhD from The George Washington University, her MBA from Meredith College, and her BA from The University of Cincinnati. Her varied research interests include celebrity endorsements, wine consumption, online teaching and the history of advertising. She has provided expert witness testimony at trial, interviews in various local and national news media and her work has been published in a number of academic and professional journals.

\section{REFERENCES}

1. Adams-Price, Carolyn and A. L. Greene (1990), "Secondary Attachments and Adolescent Self-Concept", Sex Roles, Vol. 22, Nos. 3/4, 187-198.

2. $\quad$ Atkin, Chares and Martin Block (1983), Journal of Advertising Research, Feb-Mar Vol. 23, Iss. 1, pp. 5761.

3. Basil, Michael D. (1996), "Identification as a Mediator of Celebrity Effects," Journal of Broadcasting and Electronic Media, Vol. 40, Iss. 4, Fall, 478-495.

4. Bonham, Dean (2000), "From Billie Jean to Venus, Our Female Athletes have Triumphed," Denver Rocky Mountain News, December 10, 2000.

5. Buhr, Thomas A., Terry L. Simpson and Burt Pryor (1987), "Celebrity Endorsers' Expertise and Perceptions of Attractiveness, Likeability, and Familiarity," Psychological Reports, Vol. 60, pp. 13071309.

6. Bush, Alan J., Craig A. and Victoria D. Bush (2004), "Sports Celebrity Influence of Behavioral Intentions of Generation Y," Journal of Advertising Research, Vol. 44 Iss. March, p108-118, 11p.

7. Duke, Lisa and Peggy Kreshel (1998), "Negotiating Femininity: Girls in Early Adolescence Read Teen Magazines," Journal of Communication Inquiry, Vol. 22, no. 1, pp48-72.

8. Ebenkamp, Becky (2004), "Battle of the Net Worth Stars," Brandweek, New York: Dec 13, 2004. Vol. 45, Iss. $45 ;$ pg. 20,1 pgs.

9. $\quad$ Erdogan, B. Zafer (1999), “Celebrity Endorsement: A Literature Review,” Journal of Marketing Management, Vol. 15, Iss. 4, pp. 291-314.

10. Fink, Janet S. (1998), "Female Athletes and the Media," Journal of Physical Education, Recreation and Dance; 1998 Vol. 69 Iss. August, p37-45, 9p.

11. Fink, Janet and Heidi Parker (2004), "Female Athletes as Endorsers: What Variables Influence Effectiveness," Presented at the 2008 North American Society for Sport Management Conference (NASSM 2008), Toronto, Canada, May 28-31,2008, pp 151.

12. Friedman, Hershey, and Linda Friedman (1979), "Endorser Effectiveness by Product Type," Journal of Advertising Research, Vol. 19, Iss. 5, pp. 63-71.

13. Goldman, Kevin, "Women endorsers more credible than men, a survey suggests", Wall Street Journal, Print Media Edition:Eastern edition, New York, N.Y. Oct 12, 1995

14. Grau, Stacy Landreth, Georgina Roselli, and Charles R Taylor (2007), "Where's Tamika Catchings? A Content Analysis of Female Athlete Endorsers in Magazine Advertisements," Journal of Current Issues and Research in Advertising. Clemson: Spring 2007. Vol. 29, Iss. 1; p. 55. 
15. Kahle, Lynn R. and Pamela M. Homer (1985), "Physical Attractiveness of the Celebrity Endorser: A Social Adaptation Perspective," Journal of Consumer Research, Vol. 11, March, pp. 54-961.

16. Kahle, Lynn R. and Chris Riley (2004), Sports Marketing and the Psychology of Marketing Communication, Lawrence Erlbaum Associates, Mahwah, NJ. Publication, 2004.

17. Kaikati, Jack G. (1987), "Celebrity Advertising: A Review and Synthesis," International Journal of Advertising, Vol. Iss. 6, pp. 93-105.

18. http://www.kff.org/entmedia/upload/Tweens-Teens-and-Magazines-Fact-Sheet.pdf

19. Kamins, Michael A. (1989), "Celebrity and Noncelebrity Advertising in a Two-sided Context," Journal of Advertising Research, June/July, pp. 34-42.

20. - (1990), "An Investigation into the "Match-Up" Hypothesis in Celebrity Advertising: When Beauty May be Only Skin Deep," Journal of Advertising, Vol. 19, Iss. 1, pp. 4-13.

21. - Michael A., Meribeth J. Brand, Stuart A. Hoeke, and John C. Moe (1989), "Two-sided Versus One-sided Celebrity Endorsements: The Impact on Advertising Effectiveness and Credibility," Journal of Advertising, Vol. 18, Iss. 2, pp. 4-10.

22. Kelman, Herbert C. (1961), "Processes of Opinion Change," Public Opinion Quarterly, Vol. 25 (Winter), pp. 57-78.

23. Kolbe, Richard and Melissa A. Burnett (1991), "Content Analysis Research: An Examination of Applications with Directives for Improving Research Reliability and Objectivity," Journal of Consumer Research, Vol. 18 (September), pp. 243-2

24. Kover, Arthur J., Stephen M. Goldberg, and William L. James (1995), "Creativity vs. Effectiveness? An Integrating Classification for Advertising," Journal of Advertising Research, Vol. 35, Iss. 6, NovemberDecember, pp. 29-38.

25. Lockwood, Penelope, and Ziva Kunda (1997), "Superstars and me: Predicting the impact of Role Models on the Self," Journal of Personality and Social Psychology, Vol. 73, Iss. 1, July, pp. 91-103.

26. Maddux, James E. and Ronald W. Rogers (1980), "Effects of Source Expertness, Physical Attractiveness, and Supporting Arguments on Persuasion: A Case of Brains over Beauty," Journal of Personality and Social Psychology, Vol. 39, August, pp. 235-244.

27. http://magazine.org

28. McCracken, Grant (1989), "Who is the Celebrity Endorser? Cultural Foundations of the Endorsement Process," Journal of Consumer Research, Vol. 16, December, pp. 310-321.

29. Norman, Nancy M. and James T. Tedeschi (1989), "Self-Presentation, Reasoned Action, and Adolescent Decisions to Smoke Cigarettes," Journal of Applied Social Psychology, Vol. 19, Iss. 7, pp. 543-558.

30. Ohanian, Roobina (1991), "The Impact of Celebrity Spokespersons' Perceived Image on Consumers' Intention to Purchase," Journal of Advertising Research, February/March, pp. 46-54.

31. Perreault, W.D. Jr and Leigh, L.E. (1989), "Reliability of nominal data based on qualitative judgements", Journal of Marketing Research, Vol. 26, No. 2, pp. 135-48.

32. Petty, Richard E., John T. Cacioppo and David Schumann, (1983), "Central and Peripheral Routes to Advertising Effectiveness: The Moderating Role of Involvement," Journal of Consumer Research, Vol. 10, Iss. 2, pp. 135-142.

33. Reichert, Tom; Jaqueline Lambiase, Susan Morgan, Meta Carstarphen, and Susan Zavonia, (1999), "Cheesecake and Beefcake: No Matter How You Slice It, Sexual Explicitness in Advertising Continues to Increase;," Journalism and Mass Communication Quarterly; 1999 Vol. 76 Iss. Spring, p7-20, 14p.

34. Sellers, Patricia (1989), "The ABCs of Marketing to Kids," Fortune, May 8, 1989, V119 No. 10, pp. 114120.

35. Shani, David and Dennis Sandler (1991), "Marketing News, Vol. 25, No. 16, pp. 8.

36. Solomon, Michael R. (1983), "The Role of Products as Social Stimuli: A Symbolic Interactionism Perspective," Journal of Consumer Research, Vol. 10, December, pp. 319-329.

37. Spencer, N.E. and L.R. McClung (2001), "Women and Sport in the 1990s: Reflections on Embracing Stars, Ignoring Players," Journal of Sport Management, Vol. 15, pp.318-349.

38. http://sportsillustrated.cnn.com/vault/cover/home/index.htm

39. Stanton, Warren R., Greg D. Currie, Tian P.S. Oei, and Phil A Silva (1996), "A Developmental Approach to Influences on Adolescents' Smoking and Quitting," Journal of Applied Developmental Psychology, Vol. 17, pp. 307-319. 
40. Stevenson, Thomas H. and Patricia E. Mclntyre (1995), "A Comparison of the Portrayal and Frequency of Hispanics and Whites in English Language Television Advertising," Journal of Current Issues and Research in Advertising; Vol. 17 Iss. 1, p65-74, 10p.

41. St. James, Melissa and James Swartz (2005), "Gender as a Determinant of the Relative Merits of Celebrity Sports Figures in Magazine Advertising," Where Sport Marketing Theory Meets Practice: Selected Papers from the Second Annual Conference of the Sport Marketing Association, Nov. 2005.

42. Sullivan, Robert, "For Women: A Golden Age" Time; 9/3/2001, Vol. 158 Iss. 9, pp. 62, 2p, 2c.

43. The Taylor Research \& Consulting Group (2003), "Taylor Kids Pulse: Where the Wired Things Are," as cited in Teen Media Monitor: Teen Girls, The Kaiser Family Foundation Vol. 2, no. 1

44. Wilkes, Robert E. and Humberto Valencia, (1989), "Hispanics and Blacks in Television Commercials," Journal of Advertising Vol. 18 Iss. 1, p19-25, 7p.

45. http://www.womenssportsfoundation.org/Content/Articles/Issues/Media-and-Publicity/M/Media--Imagesand-Words-In-Womens-Sports-The-Foundation-Position.aspx; "Media-Images and Words in Women's Sports-The Foundation Position; Women's Sports Foundation; 2001. 
NOTES 